\title{
Water-Rock Simulation During Limestone Dissolution
}

\author{
Yangchen Zhang ${ }^{1,2}$, Wen Tian ${ }^{3,4}$, Xiyu $\mathbf{Q u}^{1,2^{*}}$, Shan Gao ${ }^{1}$, Sirui Chen ${ }^{1}$ and Liong Foo How ${ }^{5}$ \\ ${ }^{1}$ School of Geosciences, China University of Petroleum, Qingdao, Shandong 266580, China \\ ${ }^{2}$ Key Laboratory of Deep Oil and Gas China University of Petroleum Qingdao 266580, China \\ ${ }^{3}$ Postdoctoral Scientific Research Station of Shengli Petroleum Administration, Dongying, Shandong 257022, China \\ ${ }^{4}$ Research Institute of Petroleum Exploration and Development, Shengli Oilfield, SINOPEC, Dongying, Shandong 257000, China \\ ${ }^{5}$ Exxonmobil Asia Pacific Pte Ltd, 609434, Singapore
}

Received 7 May 2019; Accepted 11 August 2019

\begin{abstract}
Limestone reservoir plays a vital role in global oil and gas distribution. Many studies on limestone dissolution have been reported, which mainly emphasize on the main controlling factors of limestone dissolution and reservoir formation mechanism. However, few studies have been conducted on limestone dissolution laws, and a general understanding of limestone dissolution under supergene and burial conditions is lacking. A water-rock simulation experiment was conducted by using five typical Lower Paleozoic limestones in Zhuanghai area of Jiyang depression of China to study limestone dissolution laws under supergene and burial conditions. Sample characteristics were observed by scanning electron microscopy, and limestone dissolution was investigated by inductively coupled plasma optical emission spectrometer (ICP-OES). Results show that the erosion rate of limestone is higher than that of dolomite under supergene condition $\left(22{ }^{\circ} \mathrm{C}\right.$ and $\left.1.0 \mathrm{MPa}\right)$. Limestone has selective corrosion in structure and components. Calcite is generally manifested as a "corroded crystalline cone," and dolomite generally presents "honeycomb-shaped" corrosion. Under burial conditions, the erosion rate of limestone first increases, decreases, and finally increases in the range of $\left[80{ }^{\circ} \mathrm{C}, 18\right.$ $\left.\mathrm{MPa}-160{ }^{\circ} \mathrm{C}, 42 \mathrm{MPa}\right]$. In the range of $\left[120^{\circ} \mathrm{C}, 30 \mathrm{MPa}-160{ }^{\circ} \mathrm{C}, 42 \mathrm{MPa}\right]$, the erosion rate of dolomite gradually becomes higher than that of calcite, and the erosion of dolomite dominates. Dolomite easily forms secondary pores and high-quality reservoirs than limestone. In this study, the general laws of limestone dissolution were investigated, and conclusions provide references to evaluate high-quality limestone reservoirs.
\end{abstract}

Keywords: Limestone dissolution, Supergene condition, Burial condition

\section{Introduction}

Research on limestone reservoirs has recently attracted wide attention. Limestone reservoirs play an important role in oil and gas distribution in the world. Oil and gas reservoirs in limestone reservoir strata account for approximately $50 \%$ of total global oil and gas reservoirs. Oil and gas output in limestone reservoirs strata has exceeded $60 \%$ of total global oil and gas output $[1,2]$. Universal developments of limestone paleo crust of weathering and ancient dissolution reservoirs, which are related to the plane of unconformity, have been made [3]. Supergene karstification and buried karstification are the most important diagenesis for the development of limestone reservoirs [4]. Secondary pores and large cavities formed by supergene karstification and buried karstification are among the important characteristics of high-quality limestone reservoirs $[5,6]$. The development of high-quality weathering crust reservoirs is believed to be the consequence of supergene atmospheric fresh water reconstruction [7-10]. Corrosion in the buried diagenetic environment is important to the formation of pores in limestone reservoirs, thereby forming high-porosity oil and gas reservoirs [11]. Two perceptions on the corrosion rates of limestone under supergene conditions have been reported by Chinese scholars. One is limestone $>$ dolomite limestone $>$ lime-dolomite $>$ dolomite [12], and the other is

*E-mail address: quxiyu@upc.edu.cn

ISSN: 1791-2377 @ 2019 School of Science, IHU. All rights reserved.

doi:10.25103/iestr.124.06 dolomite limestone $>$ limestone $>$ lime-dolomite $>$ dolomite [13] For the corrosion rate of limestone under burial conditions, most scholars have deemed that the corrosion rate of dolomite is higher than that of limestone [12, 14-16]. Many experimental studies on limestone dissolution have been performed via the kinetic theory of limestone dissolution [14, 17], an open-system pH-free drift method [17], water-rock reaction experiment, and scanning electron microscopy (SEM) observations, and major achievements have been made. These achievements contribute to the study of limestone corrosion and evaluation of high-quality reservoirs. However, previous studies mainly focused on the controlling factors of limestone dissolution and the formation mechanism of limestone reservoirs. Only few studies discussed the corrosion laws of limestone, and a general understanding on limestone dissolution under supergene and burial conditions is lacking. In this study, a series of studies on the corrosion laws of the Lower Paleozoic limestone in Zhuanghai area under supergene and burial conditions was conducted. The basic corrosion laws of limestone were summarized, which provide references for the quality of high-quality limestone reservoirs.

\section{State of the art}

Supergene karstification and buried dissolution are important diageneses of limestone dissolution. With largescale detection of limestone reservoirs in recent years, 
research on limestone reservoirs is attracting increasing attention. A series of studies on the main controlling factors of limestone dissolution has been reported. Gledhill et al. studied the dissolution kinetics of calcite in saline by using an open-system $\mathrm{pH}$-free drift method; they found that the temperature and partial pressure of $\mathrm{CO}_{2}$ rather than salinity are the main influencing factors of the dissolution rate [17]. Elkhoury et al. proposed a reactive transport model to explore the effects of fluid properties and flow rate on dissolution [18]. Ellis et al. studied fractured limestone by X-ray diffraction (XRD) imaging and disclosed a nonintuitive inverse relationship between cover dissolution of fractured limestone and permeability evolution [19]. Garing et al. measured the changes in fracture volume induced by calcite dissolution and gypsum precipitation through X-ray computer microtomography and water chemistry. They found that changes in the permeability of fractures depend highly on flow rate and dissolution mode [20]. Smith et al. investigated low-permeability limestone dissolution induced by $\mathrm{CO}_{2}$ through in situ observation and concluded that the constant of calcite reaction rate is about 17 times that of dolomite [21, 22]. Menke et al. analyzed the effects of pores on limestone dissolution through in situ observation and found that limestone dissolution is restricted by pore-scale transmission of reactants [23]. Ghommem et al. proposed a 3D core-scale prediction model for the acidification of limestone [24]. Fan et al. discussed the differences between the dissolution of limestone and dolomite through a differential dissolution simulation experiment and found that the mineral composition of limestone is the main influencing factor for the differential dissolution of limestone [25]. She et al. studied the dissolution laws and pore evolutions of limestone in a limestone dissolution experiment in acetic acid. They determined that the dissolution volume of limestone is inversely proportional to temperature but proportional to pressure. Temperature influences the dissolution volume of limestone more considerably than pressure [26]. Peng et al. discussed the limestone dissolution mechanism through a dissolution simulation experiment and controlled selective dissolution by mineral composition and reservoir space types of limestone. The limestone dissolution capability of acid fluid initially increases and then decreases, thereby exhibiting an optimal temperature and pressure range for limestone dissolution [27]. Shou et al. studied the reconstruction effect of limestone dissolution under strata conditions and relevant controlling factors through a simulation experiment of seepage and reaction of fluids in pores-fractures of rocks. The dissolution capacity of limestone was found to decrease gradually rather than increase with the increase in strata temperature. Pressure presented a weak positive correlation with the dissolution capacity of limestone [28]. All of these previous studies focused on the main controlling factors of limestone dissolution. However, the effects of the main controlling factors on the dissolution behavior of different types of limestone have not been discussed in detail. Existing studies mainly reported the effects of a single main controlling factor on the dissolution of two types of limestone. The dissolution of different types of limestone under collaborative controlling conditions of multiple factors has yet to be explored.

A series of studies on limestone dissolution under supergene and burial conditions was performed to disclose limestone dissolution characteristics and mechanism and limestone dissolution conditions under different temperatures and pressures. Pokrovsky et al. discussed the activation energy of limestone dissolution under different temperatures and $\mathrm{pCO}_{2}$ and found that high temperature and $\mathrm{pCO}_{2}$ might decrease the reactivity of carbonate minerals in aqueous solution [29, 30]. Alkattan et al. determined the dissolution rates of single calcite crystal, limestone, and compressed calcite powder following the mass loss of samples by using the free drifting rotary disk technology. Test results indicated that the dissolution rates of single calcite crystal, limestone, and compressed calcite powder are the same under acid conditions [31]. Zhu et al. observed the surface characteristics and mechanism of limestone dissolution through a dissolution experiment in acetic acid and hydrochloric acid; calcite and dolomite exhibit a unique dissolution phenomenon, and limestone presents a small content of dolomite that can accelerate dissolution [32]. Yang et al. performed a simulation experiment on the dissolution-induced diagenetic processes of limestone with different compositions under supergene and burial conditions and identified that the dissolution rate of limestone is related to mineral composition. Under nearsurface conditions, the dissolution rate is positively related to calcite content. The dissolution rate of calcite is significantly lower than that of dolomite when temperature is higher than $75^{\circ} \mathrm{C}$ and pressure exceeds $20 \mathrm{MPa}$ [12]. She et al. analyzed the reconstruction mechanism of organic acid to limestone reservoirs from supergene to deep buried environments by a dissolution kinetic experiment. They reported that the types and connectivity of pores formed by limestone dissolution are closely related to the formation of favorable limestone reservoirs $[14,15]$. Tan et al. conducted a dissolution simulation experiment based on $\mathrm{CO}_{2}$ solution and acetic acid solution to discuss the influences of temperature, pressure, and fluid on the karstification of different minerals and limestones under burial conditions. The dissolution rate of limestone was found to increase with the increase in calcite content. Under deep burial conditions, the influences of mineral composition on dissolution rate are weak [33]. Jiang et al. performed a dissolution simulation experiment by using $\mathrm{CO}_{2}$, acetic acid, and $\mathrm{H}_{2} \mathrm{~S}$ solution to investigate the dissolution of calcite and dolomite under single controlling factors of temperature or pressure. Given the same pressure, limestone is the easiest to be dissolved, whereas dolomite is the most difficult to be dissolved. The dissolubility of transition rock is between those of limestone and dolomite. Under the same temperature, limestone is the easiest to be dissolved in the pressure range of $0.2-30 \mathrm{MPa}$, but dolomite is easily dissolved after $50 \mathrm{MPa}$ [11]. These studies discussed the dissolution characteristics and mechanism of limestone under supergene and burial conditions and achieved outstanding findings. However, none of these studies explored the basic dissolution laws of different limestones, thereby failing to acquire a universal understanding in limestone dissolution laws under supergene and burial conditions.

To address the shortcomings of existing studies, this study summarizes the general dissolution laws of limestone under supergene and burial conditions intuitively through SEM images, water sample test, mass loss rate, and changes in $\mathrm{Ca}^{2+}$ and $\mathrm{Mg}^{2+}$ concentrations before and after the dissolution. Research conclusions provide references to assess limestone dissolution and high-quality limestone reservoirs. 
The remainder of this study is organized as follows. Section 3 introduces the research methods. Section 4 analyzes the experimental results and summarizes the general laws of limestone dissolution under supergene and burial conditions. Section 5 concludes the study.

\section{Methodology}

\subsection{Experimental samples}

Experimental samples were drilling cores collected from CB302 (drilling depth=3543.8 m), CB302-2 (drilling depth $=3537.95 \mathrm{~m}$ ), CB304 (drilling depths $=3367.46$ and $3375.8 \mathrm{~m}$ ), and CB306 (drilling depth=4398 m) at approximately 3000-4000 m deep Cambria and Ordovician strata in Zhuanghai area. Samples were named based on sheet observation and full-rock XRD analysis. The XRD analysis results showed that calcite and dolomite were the main mineral components of experimental samples. Few feldspars, quartz, and clay minerals were determined. Therefore, experimental samples were named as dolomite, lime-dolomite, limestone, dolomite limestone, and ooidlimestone.

The sheet pictures show that dolomite from CB304 was highly developed with intergranular pores (Fig. 1a). However, few pores were observed in lime-dolomite (Fig. 1b) and limestone from CB302-2 (Fig. 1c). Many cracks were noted in dolomite limestone from CB302, which were expanded by karstification in the late period (Fig. 1d). Stylolites were developed in ooid-limestone samples from CB306, with asphaltenes. Dolomite was developed at stylolites (Fig. 1e).

Table1. XRD analyses of carbonate rocks

\begin{tabular}{c|c|c|c|c|c|c|c|c}
\hline Well number & Depth/m & Lithology & Quartz & Feldspar & Calcite & Dolomite & Pyrite & Clay minerals \\
\hline CB304 & 3367.46 & Dolomite & 2 & 1 & 1 & 95 & - & \\
CB304 & 3375.8 & Lime-dolomite & 7 & - & 15 & 76 \\
CB302-2 & 3537.95 & Limestone & 3 & - & 93 & 2 & - \\
CB302 & 3543.8 & Dolomite limestone & 2 & - & 80 & 17 & - \\
CB306 & 4398 & Ooid-limestone & 1 & - & 80 & 17 & - \\
\hline
\end{tabular}

Note: The horizontal line indicates that it has not been detected or is below the detection limit.

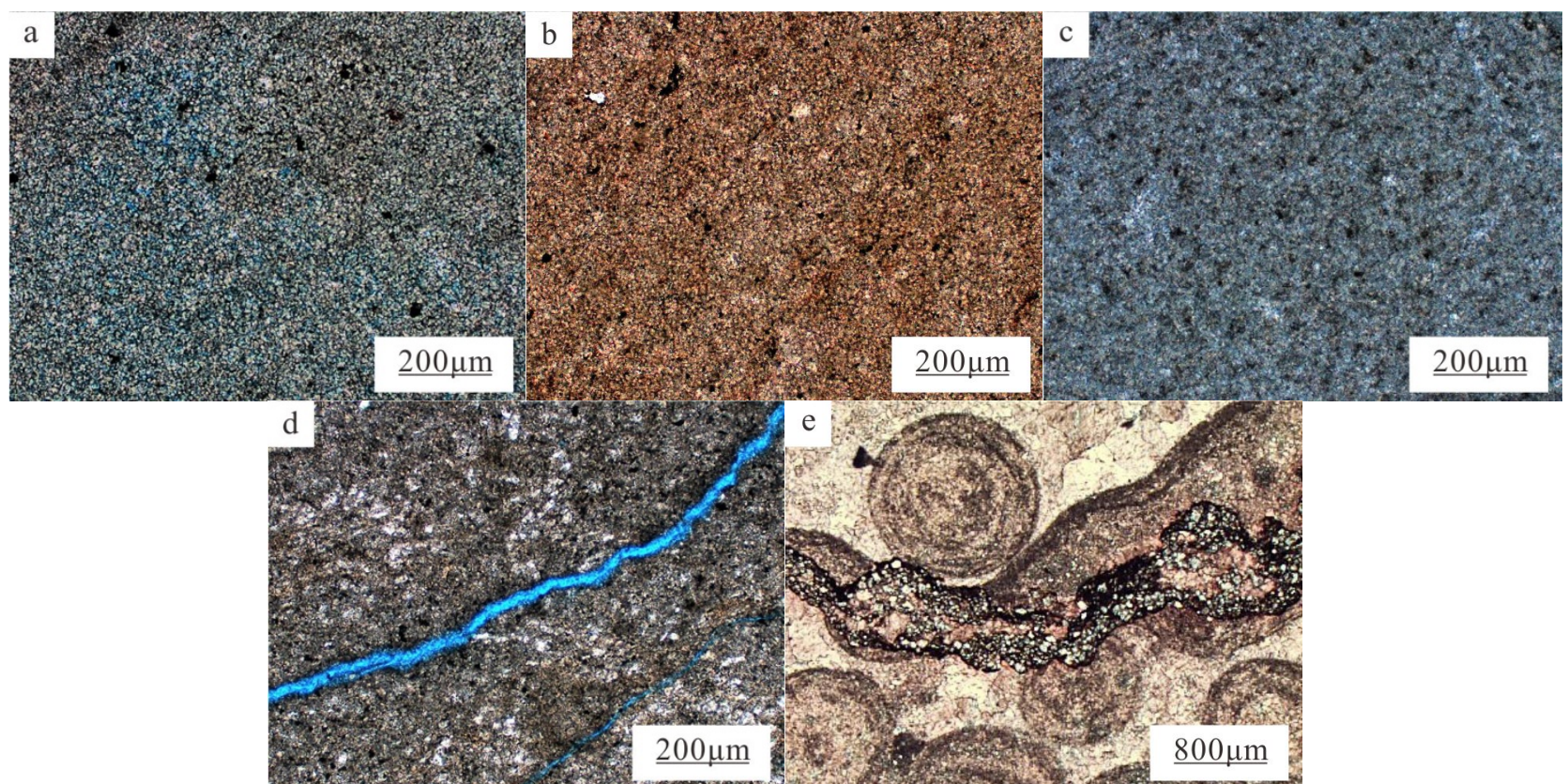

Note: a-Dolomite, inter-granular pore development, single polar, 10×10, $3367.46 \mathrm{~m}, \mathrm{CB} 304$ well; b-Lime-dolomite, undeveloped porosity, single polar, 10×10, $3375.8 \mathrm{~m}, \mathrm{CB} 304$ well; c-Limestone, undeveloped porosity, 10×10, $3537.95 \mathrm{~m}, \mathrm{CB} 302-2$ well; c-Dolomitic limestone, crack development, enlarged crack at the later stage by erosion, 10×10, $3543.8 \mathrm{~m}, \mathrm{CB} 302$ well; e-Ooid-limestone, developed stylolites in ooid-limestone, with asphaltenes, Developed dolomite at stylolites, 40×10, $4398 \mathrm{~m}, \mathrm{CB} 306$ well

Fig. 1. Microscopic characteristics of carbonate rocks from Zhuanghai area

\subsection{Experimental process}

\subsubsection{Supergene experimental process}

In this experiment, $10 \mathrm{~mL}(3.6 \mathrm{~g})$ of concentrated hydrochloric acid (36\%) was diluted to $1 \mathrm{~L}$ of water, with a concentration of $3.6 \mathrm{~g} / \mathrm{L}$ and $\mathrm{pH} 1.0$. Subsequently, $100 \mathrm{~mL}$ of diluents was collected and further diluted to $1 \mathrm{~L}$ and $\mathrm{pH}$ 2.0 [32].

Samples were ground to small pieces with similar size (approximately 2.5-2.8 g). Some samples were slightly lighter than $2.5 \mathrm{~g}$ due to limited samples. All samples were weighed and placed in $100 \mathrm{~mL}$ of prepared acid solution to react for $24 \mathrm{~h}$ under normal pressure and temperature (1
$\mathrm{MPa}$ and $22{ }^{\circ} \mathrm{C}$ ). Samples were collected, dried for $24 \mathrm{~h}$ at the end of experiment, and weighed. The reacted rock samples were observed by an S4800 cold field emission SEM.

\subsubsection{Buried experimental process}

In this experiment, $2.9 \mathrm{~mL}$ of formic acid was diluted to $1 \mathrm{~L}$ of water, and $10 \mathrm{~mL}$ of diluents was collected for later use. Subsequently, $4 \mathrm{~mL}$ of acetic acid was diluted to $1 \mathrm{~L}$ of water, and $10 \mathrm{~mL}$ of diluents was collected for later use. The prepared $10 \mathrm{~mL}$ of formic acid diluents and $10 \mathrm{~mL}$ of acetic acid diluents were mixed and then diluted to $1 \mathrm{~L}$, and $10 \mathrm{~mL}$ of diluents was collected. Approximately $3 \mathrm{~g}$ of oxalic acid was weighed by an electronic balance and prepared into $1 \mathrm{~L}$ 
of solution, in which $10 \mathrm{~mL}$ of diluents was collected. The mixture of formic and acetic acid solutions $(10 \mathrm{~mL})$ was added with $10 \mathrm{~mL}$ of oxalic acid diluents and diluted to $1 \mathrm{~L}$. The mixture $(500 \mathrm{~mL})$ was used as the acid solution in each buried simulation experiment. The $\mathrm{pH}$ of the mixture was measured as 3.71 by a $\mathrm{pH}$ meter.

Samples were weighed. The ground test samples and prepared $500 \mathrm{~mL}$ of mixture were placed in a hightemperature and high-pressure reactor. The reactor was closed, and the temperature was adjusted. Nitrogen was supplied to make the pressure in the reactor slightly lower than the target pressure. When the temperature was stabilized after $3 \mathrm{~h}$, nitrogen was supplied or discharged to make the pressure in the reactor equal to the target pressure. The samples and solution were collected at $48 \mathrm{~h}$. The samples were dried in a drying oven for $24 \mathrm{~h}$ and weighed. The solution was tested by ICP-OES instrument. Reacted rock samples were observed by an S4800 cold field emission SEM.

\section{Result Analysis and Discussion}

Rock samples after the reaction were observed by an S4800 cold field emission SEM. limestone samples developed different degrees of karstification under supergene and burial conditions (Fig. 2). The sample surface was uneven, with dissolution pores (Figs. $2 \mathrm{~d}_{2}, \mathrm{a}_{3}, \mathrm{c}_{3}$, and $\mathrm{e}_{3}$ ) and fractures

(Fig. $2 \mathrm{e}_{2}$ ). Some samples dissolved out a single crystal form
(Figs. $2 \mathrm{a}_{2}, \mathrm{~b}_{2}, \mathrm{c}_{2}$, and $\mathrm{d}_{3}$ ). Some samples showed mild karstification, with surface dissolution (Fig. $2 b_{3}$ ).

\subsection{Dissolution simulation experiment of supergene conditions}

4.1.1 Analysis of dissolution degree and ion concentration The experimental results (Tables 2 and 3) show that the dissolution rates of limestone under normal pressure and temperature were dolomite limestone $>$ ooidlimestone $>$ limestone $>$ lime-dolomite $>$ dolomite. For dolomite and Lime-dolomite, the change rate of mass and the releasing amounts of $\mathrm{Ca}^{2+}$ and $\mathrm{Mg}^{2+}$ revealed some errors. The total dissolution law indicates that the dissolution rate of limestone is considerably higher than that of dolomite under supergene conditions. This result implied that the dissolution rate of calcite was higher than that of dolomite under supergene conditions, which conformed to previous research conclusions. The dissolution rate of dolomite limestone (dolomite content $=17 \%$ ) was higher than that of limestone, which indicated that few dolomite in limestone could accelerate karstification. This phenomenon may be because $\mathrm{Mg}^{2+}$ enters into calcite crystals to combine with lattices, thereby increasing the dissolubility of calcite [34]. The limit of the $\mathrm{Mg}^{2+}$ content is $\mathrm{Mg}$ : $\mathrm{Ca}=0.045$ (mass fraction) [35]. This phenomenon is called the "salting-in effect" [13].

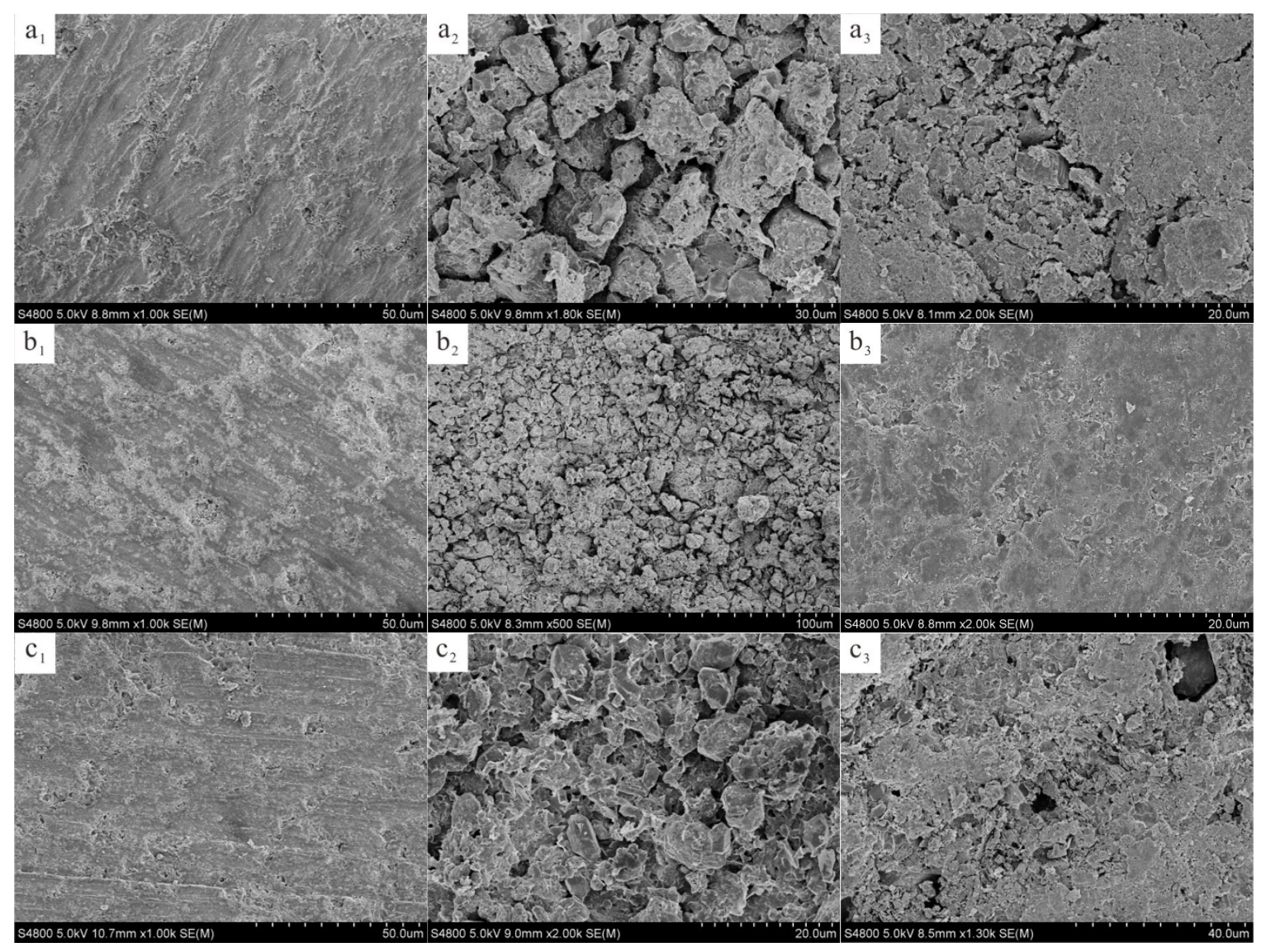




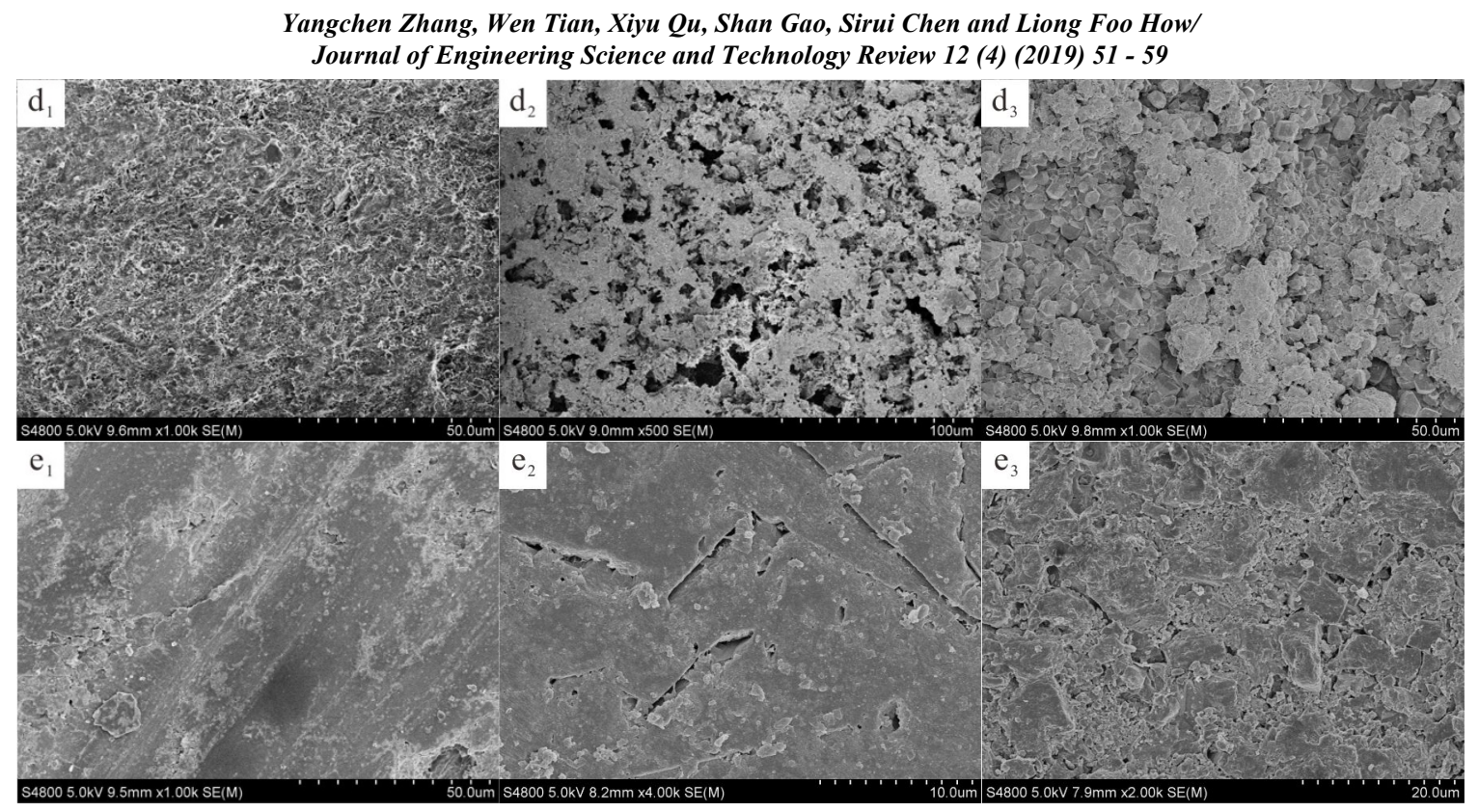

Note: $\left(a_{1}-e_{1}\right)$ : Carbonate sample before reaction; $\left(a_{2}-e_{2}\right)$ : Carbonate samples under epigenetic conditions; $a_{2}-c_{2}$ : Dissolved sample appears as a single crystal; $d_{2}$ : Eroded holes and deeper dissolution; $e_{2}$ : Corrosion cracks are relatively developed; $\left(a_{3}-e_{3}\right)$ : Carbonate samples under burial conditions; $\mathrm{a}_{3}: 140{ }^{\circ} \mathrm{C}, 36 \mathrm{MPa}$, Corrosion is comparatively serious, the surface is covered by residual clay minerals, and corrosion holes are relatively developed; $\mathrm{b}_{3}: 120^{\circ} \mathrm{C}, 30 \mathrm{MPa}$, Low degree of dissolution, a small dissolved hole can be seen on the surface; $\mathrm{c}_{3}: 160{ }^{\circ} \mathrm{C}, 42 \mathrm{MPa}$, Corrosion is comparatively serious, and deep dissolved holes appear; $\mathrm{d}_{3}: 100{ }^{\circ} \mathrm{C}, 24 \mathrm{MPa}$, Mainly manifested as surface erosion, revealing internal crystal morphology; $\mathrm{e}_{3}: 80^{\circ} \mathrm{C}, 18 \mathrm{MPa}$, Corrosion is serious, and caves appear; $\left(\mathrm{a}_{1}-\mathrm{a}_{3}\right.$ : Dolomite; $\mathrm{b}_{1}-\mathrm{b}_{3}:$ Lime-dolomite; $\mathrm{c}_{1}-\mathrm{c}_{3}$ : Limestone; $\mathrm{d}_{1}-\mathrm{d}_{3}$ : Cloudy limestone; $\mathrm{e}_{1}-\mathrm{e}_{3}$ : Ooid-limestone)

Fig. 2. Morphology of carbonate rock samples before and after dissolution

Table 2. Quality changes and order of dissolution of carbonate rocks before and after reaction under epigenetic conditions

\begin{tabular}{|c|c|c|c|c|c|c|}
\hline Lithology & $\begin{array}{l}\text { Pre-reaction } \\
\text { quality /g }\end{array}$ & $\begin{array}{l}\text { Quality after } \\
\text { reaction/g }\end{array}$ & Quality of loss /g & $\begin{array}{l}\text { Relative change } \\
\text { in mass } / \%\end{array}$ & $\begin{array}{l}\text { Average rate of } \\
\text { change in mass } \\
/ \%\end{array}$ & $\begin{array}{l}\text { Order of } \\
\text { dissolution }\end{array}$ \\
\hline Dolomite & $\begin{array}{l}2.46 \\
2.28 \\
\end{array}$ & $\begin{array}{l}2.44 \\
2.26 \\
\end{array}$ & $\begin{array}{l}0.02 \\
0.02\end{array}$ & $\begin{array}{l}0.81 \\
0.88\end{array}$ & 0.845 & 5 \\
\hline Lime-dolomite & $\begin{array}{l}2.83 \\
2.88 \\
\end{array}$ & $\begin{array}{l}2.80 \\
2.86 \\
\end{array}$ & $\begin{array}{l}0.03 \\
0.02 \\
\end{array}$ & $\begin{array}{l}1.06 \\
0.69 \\
\end{array}$ & 0.877 & 4 \\
\hline Limestone & $\begin{array}{l}2.72 \\
2.42 \\
\end{array}$ & $\begin{array}{l}2.70 \\
2.39 \\
\end{array}$ & $\begin{array}{l}0.02 \\
0.03 \\
\end{array}$ & $\begin{array}{l}0.74 \\
1.24 \\
\end{array}$ & 0.987 & 3 \\
\hline Ooid-limestone & $\begin{array}{l}2.65 \\
2.67\end{array}$ & $\begin{array}{l}2.62 \\
2.64\end{array}$ & $\begin{array}{l}0.03 \\
0.03\end{array}$ & $\begin{array}{l}1.13 \\
1.12\end{array}$ & 1.128 & 2 \\
\hline $\begin{array}{l}\text { Dolomite } \\
\text { limestone }\end{array}$ & $\begin{array}{l}2.64 \\
2.61\end{array}$ & $\begin{array}{l}2.61 \\
2.58\end{array}$ & $\begin{array}{l}0.03 \\
0.03\end{array}$ & $\begin{array}{l}1.14 \\
1.15\end{array}$ & 1.143 & 1 \\
\hline
\end{tabular}

Table 3. Dissolution status of carbonate rocks under epigenetic condition

\begin{tabular}{c|c|c|c}
\hline Lithology & $\begin{array}{c}\mathrm{Ca}^{2+} / \mathbf{m g} / \\
\mathbf{l}\end{array}$ & $\begin{array}{c}\mathrm{Mg}^{2+} / \mathbf{m g} / \\
\mathbf{l}\end{array}$ & $\begin{array}{c}\mathrm{Ca}^{2+}+\mathrm{Mg}^{2+} / \mathbf{m g} / \\
\mathbf{l}\end{array}$ \\
\hline Dolomite & 133.7 & 69.75 & 203.45 \\
Lime-dolomite & 134.3 & 63.52 & 197.82 \\
Limestone & 248.3 & 3.42 & 251.72 \\
Ooid-limestone & 249.3 & 5.50 & 254.80 \\
Dolomite limestone & 268.8 & 44.43 & 313.23 \\
\hline
\end{tabular}

\subsubsection{Dissolution characteristics of limestone}

The micro dissolution characteristics of experimental samples were observed by an S4800 cold field emission SEM. Under supergene conditions, calcite and dolomite have selective dissolution $[6,32]$. On the basis of previous studies, selective dissolution refers to the dissolution of acid fluid at positions with weak ion and molecular binding force, such as lattice defects, dislocation, cleavage plane, and intersections [36]. This phenomenon is caused by limitations on mineral crystallization trends and crystallization conditions. Moreover, the dissolution rate varies on different crystallization directions. Edges of mineral crystals are favorable positions for selective dissolution because mineral crystallization extends from the center (crystal nucleus) to outside. It often leads to incomplete crystals at edges due to limited material sources and crystallization spaces, thereby leaving many lattice vacancies or lattice distortions. Factors that cause lattice distortion may facilitate the easy dissolution of the lattice [37]. In the study area, the dissolution of calcite is mainly manifested by a "dissolution crystalline cone" (Fig. 3a) or dissolution along edges. Edges become "crystalline cone" caused by dissolution (Figs. 3b and 3c). Dolomite is mainly manifested by "stair-shaped" 
(Fig. 3g), and regular dissolution along particle edges (Figs. $3 \mathrm{~h}$ and $3 \mathrm{i}$ ).

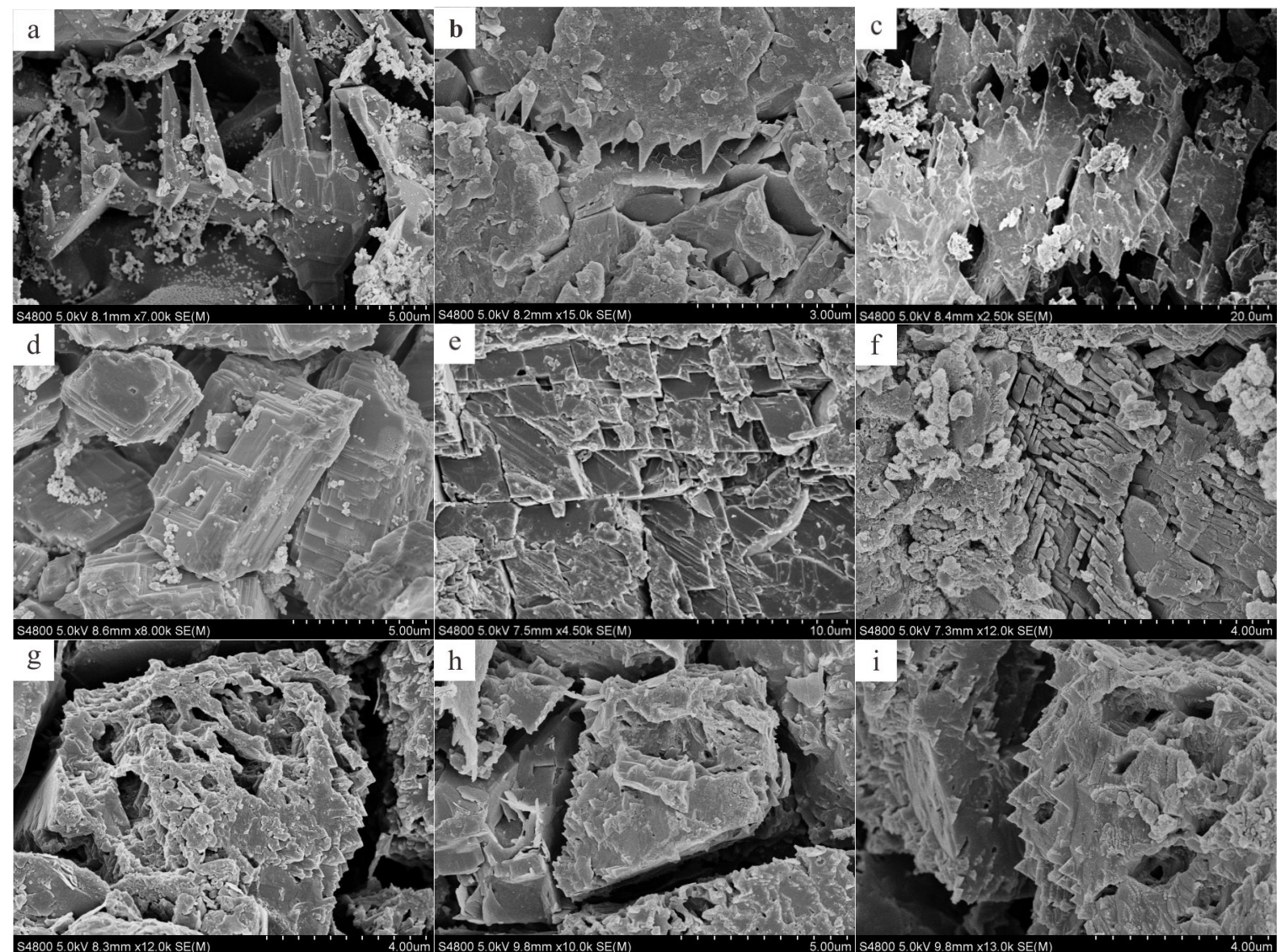

Note: a-Dolomitic limestone, calcite is dissolved into a "dissolved crystal cone," $3375.8 \mathrm{~m}, \mathrm{CB} 304$ well; b-Ooid-limestone, calcite is dissolved along particle edges, $4398 \mathrm{~m}$, CB306 well; c-Ooid-limestone, calcite is dissolved along particle edges, 4398 m, CB306 well; d-Dolomite, "stepped" dissolution of dolomite, $3367.46 \mathrm{~m}$, CB304 well; e-Dolomite, dissolution of dolomite along the cleavage direction, $3367.46 \mathrm{~m}$, CB304 well; fDolomite, corrosion along the cleavage direction, particles are broken, $3367.46 \mathrm{~m}, \mathrm{CB} 304$ well; g-Dolomitic limestone, "honeycomb" dissolution of dolomite after enlargement, $3375.8 \mathrm{~m}$, CB304 well; h-Dolomite, morphology of the dolomite edge after dissolution, $3367.46 \mathrm{~m}$, CB304 well; iDolomite, morphology of the dolomite edge erosion after enlargement, $3367.46 \mathrm{~m}, \mathrm{CB} 304$ well

Fig. 3. Morphology of carbonate rock after dissolution

The major dissolution characteristics of limestone are summarized as follows:

(1) Surface dissolution: Hydrochloric acid dissolves limestone crystal surfaces gradually, forming pits and fractures on limestone crystal surfaces. The dissolution intensity of experimental samples is very high due to the low $\mathrm{pH}$ of hydrochloric acid. Dissolution pores in some samples are hollowed out, and some samples have evident internal dissolution of single crystal. Local dissolution occurs in some crystals, and only partial crystalline forms are left. Serious dissolution occurs on the dolomite surface, which shows "honeycomb" dissolution (Fig. 3g). The "stairshaped" dissolution (Fig. 3d) is also evident.

(2) Dissolution along cleavage: This dissolution phenomenon is observed in calcite and dolomite. Calcite mainly occurs as a "dissolution crystal cone" (Fig. 3a). The dissolution of dolomite along the cleavage direction is mainly manifested as "cutting strips" [32] (Fig. 3e), and some are dissolved into pieces (Fig. 3f).

(3) Dissolution along particle edges: This dissolution is common in SEM images. Calcite is mainly "sharp-edged" dissolution along particle edges (Figs. $3 \mathrm{~b}$ and $3 \mathrm{c}$ ), and dolmite also presents a similar phenomenon. However, the angle of crystalline cone in dolomite is generally larger than that of calcite, and it is approximately a right angle (Fig. 3i). When the dissolution intensity is sufficient, edge dissolution may form single dolomite particles (Fig. 3g). This phenomenon is extremely common in SEM images of experimental samples.

\subsection{Dissolution simulation experiment under burial conditions}

The experimental results (Fig. 4) show that the mass change rate of limestone dissolution presents an $\mathrm{N}$-shaped variation law with the increase in temperature and pressure. In the studied ranges of temperature and pressure, the mass change rate of limestone dissolution peaks at approximately $120^{\circ} \mathrm{C}$ and $30 \mathrm{MPa}$, but it reaches the valley at approximately $140{ }^{\circ} \mathrm{C}$ and $36 \mathrm{MPa}$. This law is reflected in the changes in the concentration sum of $\mathrm{Ca}^{2+}$ and $\mathrm{Mg}^{2+}$ (Table 4). In previous studies, the limestone dissolution capability of acid fluid first increases and then decreases [5, 27]. Therefore, the range of $\left[80{ }^{\circ} \mathrm{C}, 18 \mathrm{MPa}-120^{\circ} \mathrm{C}, 30 \mathrm{MPa}\right]$ is the best temperature and pressure range for organic acid dissolution. This range is known as the limestone dissolution window $[27,38,39]$. In the range of $\left[80{ }^{\circ} \mathrm{C}, 18 \mathrm{MPa}-160{ }^{\circ} \mathrm{C}, 42\right.$ $\mathrm{MPa}$, the mass change rate and $\mathrm{Ca}^{2+}$ and $\mathrm{Mg}^{2+}$ concentrations in dolomite and lime-dolomite are generally higher than those in ooid-limestone, limestone, and dolomite limestone. This finding indicates that the dissolution rate of dolomite is higher than that of limestone in this range. After $140{ }^{\circ} \mathrm{C}$ and $36 \mathrm{MPa}$, the $\mathrm{Ca}^{2+}$ and $\mathrm{Mg}^{2+}$ concentrations 
dissolve from dolomite, and the increase trend is considerably higher than that of limestone. With the continuous increase in temperature and pressure, dolomite is easier to be dissolved than limestone. In the range of $\left[85^{\circ} \mathrm{C}\right.$, $\left.20 \mathrm{MPa}-160{ }^{\circ} \mathrm{C}, 42 \mathrm{MPa}\right]$, the dissolution rate of limedolomite is higher than those of the rest of the mineral components. According to previous studies, involving a certain amount of calcite in dolomite can greatly increase the dissolution intensity of dolomite, which is beneficial to highquality dolomite reservoirs $[5,28]$. Lime-dolomite is an important material basis to form high-quality limestone reservoirs [25].

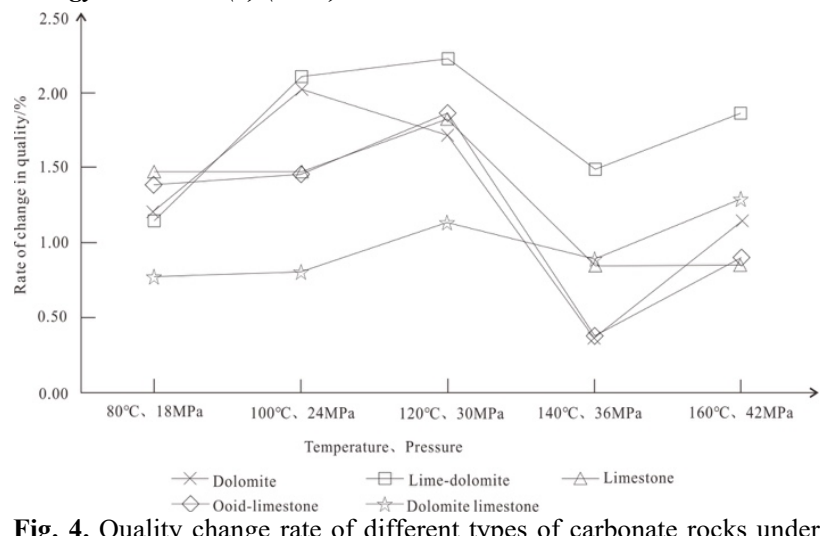

Fig. 4. Quality change rate of different types of carbonate rocks under burial conditions

Table 4. Changes in calcium and magnesium ions after the dissolution of carbonate rocks under burial conditions

\begin{tabular}{|c|c|c|c|c|c|c|}
\hline Lithology & Temperature $/{ }^{\circ} \mathbf{C}$ & Pressure /MPa & $\mathrm{Ca}^{2+} / \mathbf{m m o l} / \mathbf{l}$ & $\mathrm{Mg}^{2+} / \mathbf{m m o l} / \mathbf{l}$ & $\begin{array}{c}\mathrm{Ca}^{2+}+\mathrm{Mg}^{2+} / \mathbf{m m o l} \\
/ \mathbf{l}\end{array}$ & $\mathrm{Ca}^{2+} / \mathrm{Mg}^{2+}$ \\
\hline \multirow{5}{*}{ Dolomite } & 80 & 18 & 0.256 & 0.266 & 0.522 & 0.962 \\
\hline & 100 & 24 & 0.302 & 0.282 & 0.583 & 1.069 \\
\hline & 120 & 30 & 0.356 & 0.296 & 0.651 & 1.201 \\
\hline & 140 & 36 & 0.182 & 0.196 & 0.378 & 0.929 \\
\hline & 160 & 42 & 0.375 & 0.394 & 0.769 & 0.950 \\
\hline \multirow{5}{*}{ Lime-dolomite } & 80 & 18 & 0.294 & 0.239 & 0.533 & 1.229 \\
\hline & 100 & 24 & 0.453 & 0.334 & 0.787 & 1.357 \\
\hline & 120 & 30 & 0.496 & 0.318 & 0.814 & 1.559 \\
\hline & 140 & 36 & 0.172 & 0.191 & 0.363 & 0.897 \\
\hline & 160 & 42 & 0.206 & 0.201 & 0.407 & 1.024 \\
\hline \multirow{5}{*}{ Limestone } & 80 & 18 & 0.463 & 0.033 & 0.495 & 14.231 \\
\hline & 100 & 24 & 0.461 & 0.017 & 0.478 & 26.440 \\
\hline & 120 & 30 & 0.422 & 0.014 & 0.435 & 31.031 \\
\hline & 140 & 36 & 0.352 & 0.082 & 0.433 & 4.304 \\
\hline & 160 & 42 & 0.440 & 0.066 & 0.506 & 6.638 \\
\hline \multirow{5}{*}{ Ooid-limestone } & 80 & 18 & 0.491 & 0.024 & 0.515 & 20.530 \\
\hline & 100 & 24 & 0.441 & 0.028 & 0.469 & 15.853 \\
\hline & 120 & 30 & 0.608 & 0.016 & 0.624 & 37.512 \\
\hline & 140 & 36 & 0.412 & 0.180 & 0.342 & 0.895 \\
\hline & 160 & 42 & 0.459 & 0.116 & 0.575 & 3.948 \\
\hline \multirow{5}{*}{ Dolomite limestone } & 80 & 18 & 0.244 & 0.043 & 0.287 & 5.682 \\
\hline & 100 & 24 & 0.289 & 0.034 & 0.323 & 8.489 \\
\hline & 120 & 30 & 0.427 & 0.032 & 0.460 & 13.165 \\
\hline & 140 & 36 & 0.257 & 0.126 & 0.382 & 2.038 \\
\hline & 160 & 42 & 0.279 & 0.123 & 0.401 & 2.276 \\
\hline
\end{tabular}

The curve of the $\mathrm{Ca}^{2+}-\mathrm{Mg}^{2+}$ concentration ratio (Fig. 5) depicts that the $\mathrm{Ca}^{2+}-\mathrm{Mg}^{2+}$ concentration ratio of dolomite and lime-dolomite approaches 1 (chemometric of dolomite) in the studied range of temperature and pressure. In the range of $\left[80{ }^{\circ} \mathrm{C}, 18 \mathrm{MPa}-120^{\circ} \mathrm{C}, 30 \mathrm{MPa}\right]$, the $\mathrm{Ca}^{2+}-\mathrm{Mg}^{2+}$ concentration ratio of limestone, dolomite limestone, and ooid-limestone increases generally. The optimal dissolution temperature range for calcite in acetic acid is $80^{\circ} \mathrm{C}-120^{\circ} \mathrm{C}$, which is basically the same as previous conclusions [40]. However, the $\mathrm{Ca}^{2+}-\mathrm{Mg}^{2+}$ concentration ratio begins to decrease in the range of $\left[120^{\circ} \mathrm{C}, 30 \mathrm{MPa}-140{ }^{\circ} \mathrm{C}, 36 \mathrm{MPa}\right]$. The $\mathrm{Ca}^{2+}-\mathrm{Mg}^{2+}$ concentration ratio is much higher than 1 under $140{ }^{\circ} \mathrm{C}$ and $36 \mathrm{MPa}$. The $\mathrm{Ca}^{2+}-\mathrm{Mg}^{2+}$ concentration ratio approaches 1 in the range of $\left[140{ }^{\circ} \mathrm{C}, 36 \mathrm{MPa}-160{ }^{\circ} \mathrm{C}\right.$, $42 \mathrm{MPa}$. Hence, calcite dissolution assumes the dominant role in the three types of limestone in the range of $\left[80^{\circ} \mathrm{C}\right.$, $18 \mathrm{MPa}-140{ }^{\circ} \mathrm{C}, 36 \mathrm{MPa}$. The dissolution rate of calcite in all three types of limestone is higher than that of dolomite in the range of $\left[80^{\circ} \mathrm{C}, 18 \mathrm{MPa}-120^{\circ} \mathrm{C}, 30 \mathrm{MPa}\right.$ ]. Nevertheless, the dissolution rate of dolomite approaches that of calcite in the range of $\left[120{ }^{\circ} \mathrm{C}, 30 \mathrm{MPa}-140{ }^{\circ} \mathrm{C}, 36 \mathrm{MPa}\right]$. After $140{ }^{\circ} \mathrm{C}$ and $36 \mathrm{MPa}$, the dissolution of dolomite takes the dominant role. Dolomite is easier to form secondary pores and high-quality limestone reservoirs than limestone under deep burial conditions. 


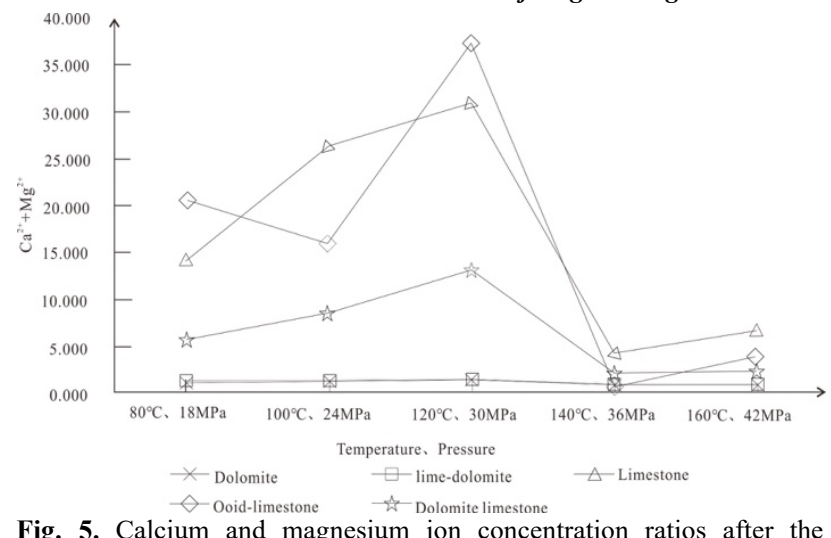

Fig. 5. Calcium and magnesium ion concentration ratios after the dissolution of carbonate rock under burial conditions

\section{Conclusions}

The dissolution characteristics of limestone under supergene conditions are discussed, and the relevant dissolution rate order is made through SEM observations and ICP-OES test to summarize the general laws of supergene and buried dissolution of limestone. The dissolution of limestone under burial conditions is also studied. The major conclusions are as follows:

(1) Under supergene conditions, the dissolution rate order of limestone is dolomite limestone $>$ ooidlimestone $>$ limestone $>$ lime-dolomite $>$ dolomite. The dissolution rate of limestone is higher than that of dolomite. The dissolution rates of dolomite limestone and ooidlimestone are higher than that of limestone. A small dolomite content in limestone can accelerate dissolution due to the "salting-in effect."

(2) Under supergene conditions, selective dissolution in the composition of limestone occurs. Specifically, limestone mainly forms a "dissolution crystal cone," and dolomite mainly presents "honeycomb" dissolution, accompanied with "cutting strip" and "stair-shaped" dissolution.

(3) The dissolution rate of lime-dolomite peaks in the studied range of temperature and pressure. In the range of $\left[80{ }^{\circ} \mathrm{C}, 18 \mathrm{MPa}-160^{\circ} \mathrm{C}, 42 \mathrm{MPa}\right]$, the mass change rate of dolomite and the $\mathrm{Ca}^{2+}$ and $\mathrm{Mg}^{2+}$ concentrations in solution are higher than those of limestone. The dissolution rate of dolomite is also higher than that of limestone. After $140{ }^{\circ} \mathrm{C}$ and $36 \mathrm{MPa}$, the dissolution of dolomite and limestone is mainly the dissolution of dolomite components. Dolomite is easier to form secondary pores and high-quality limestone reservoirs than limestone under deep burial conditions.

In this study, the general law of limestone dissolution is concluded by analyzing SEM images and $\mathrm{Ca}^{2+}$ and $\mathrm{Mg}^{2+}$ concentrations in limestone samples. This study provides references to assess high-quality limestone reservoirs. Limited by types of core samples, the dissolution law of other types of limestone in $\mathrm{CO}_{2}$ solution will be studied in future work.

\section{Acknowledgements}

This study was co-funded by the National Science and Technology Major Program of China (Grant No. 2017ZX05009-002,2017ZX05072-002), Postdoctoral Scientific Research Project of Shengli Oilfield Company (serial number: YKB1701), and Graduate Innovation Project of China University of Petroleum (East China) (YCX2019010).

This is an Open Access article distributed under the terms of the Creative Commons Attribution License

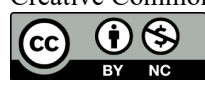

\section{References}

1. Jiang, Y. L., Zha, M., "Petroleum and natural gas geology and exploration". Beijing: Petroleum industry press, China, 2016, pp.110-120.

2. Burchette, T. P., "Carbonate rocks and petroleum reservoirs: a geological perspective from the industry". Geological Society Special Publication, 370(1), 2012, pp.17-37.

3. Chen, X. S., Yi, W. X., Lu, W. Z., "The paleokarst reservoirs of oil/gas field in China”. Acta Sedimentologica Sinica, 22(2), 2004, pp.244-252.

4. Qian, Y. X., Tabemer, C., Zou, S. L., You, D. H., Wang, R. Y. "Diagenesis comparison between epigenic karstification and burial dissolution in carbonate reservoirs: An instance of Ordovician carbonate reservoirs in Tabei and Tazhong regions, Tarim basin". Marine Origin Petroleum Geology, 12(02), 2007, pp.1-7.

5. Fan, M., Hu, K., Jiang, X. Q., Liu, W. X., Zhang, J. Y., Chen, H. Y., "Effect of acid fluid on carbonate reservoir reconstruction". Geochemistry, 38(01), 2009, pp.20-26.

6. She, M., Zhu, Y., Shen, A. J., Zheng, X. P., He, X. Y., "Simulation experimental study on carbonate rock erosion in Yingshan formation of north slope in Tazhong". Carsologica Sinica, 31(03), 2012, pp.234-239.

7. Yuan, J., "Characteristics of Lower Paleozoic buried hill reservoirs in Chengbei-30 tract". Natural Gas Industry, 2004, 24(11), pp.2225.

8. Lin, H. X., "Karstification of Lower Paleozoic reservoir in the Zhuangxi-Chengdao area, Jiyang sag, China". Journal of Chengdu University of Technology (Science \& Technology Edition), 31(5), 2004, pp.490-497.
9. Cui, D., Xu, S. M., Wang, J. D., Yu, J. G., Han, W. G., "The developmental modes of buried modification in Lower Paleozoic buried hill in Zhuanghai area of Jiyang depression". Marine Geology \& Quaternary Geology, 28(3), 2008, pp.93-102.

10. Wang, Y. S., "Characteristics and forming mechanism of buried hill reservoir of Lower Paleozoic in Zhuangxi-Chengdao area". Lithologic Reservoirs, 21(1), 2009, pp.11-14.

11. Jiang, X. Q., Wang, S. Y., Fan, M., Zhang, J. Y., Guan, H. L., Bao Y J., "Study of simulation experiment for carbonate rocks dissolution in burial diagenetic environment". Petroleum Geology \& Experiment, 30(06), 2008, pp.643-646.

12. Yang, J. J., Huang, S. J., Zhang, W. Z., Huang, Y. M., Liu, G. X., Xiao, L. P., "Experimental simulation of dissolution and diagenesis of carbonates with different compositions under thermo-stress conditions of epigenetic and burial diagenesis". Acta Sedimentologica Sinica, 13(04), 1995, pp.49-54.

13. Weng, J. T., "The differential corrosion of calcites and dolomites". Carsologica Sinica, 1984(01), 1984, pp.31-40+107-108.

14. She, M., Shou, J. F., Shen, A. J., Zhu, Y., Zheng, X. P., "Experimental simulation of dissolution for carbonate rocks in organic acid under the conditions from epigenesis to deep burial environments". Geochemistry, 43(03), 2014, pp.276-286.

15. She, M., Shou, J. F., He, X. Y., Wang, Y., Zhu, Y., Wang, Y., "Experiment of discussion mechanism of carbonate rocks: Surface dissolution and internal dissolution". Marine Origin Petroleum Geology, 18(03), 2013, pp.55-61.

16. Cao, Z. H., Liu, G. Y., Zhang, H. C., Qu, X. Y., Zhang, M. L., Shi, Z., "Experimental research of carbonate rocks dissolution characteristics in Paleozoic group of Nanpu Sag and surrounding bulge areas". Journal of China University of Petroleum (Edition of Natural Science), 38(01), 2014, pp.8-13. 
17. Gledhill, D. K., Morse, J. W., "Calcite dissolution kinetics in NaCa-Mg-Cl brines". Geochimica et Cosmochimica Acta, 70(23), 2006, pp.5802-581.

18. Elkhoury, J. E., Ameli, P., Detwiler, R. L., "Dissolution and deformation in fractured carbonates caused by flow of $\mathrm{CO}_{2}$-rich brine under reservoir conditions". International Journal of Greenhouse Gas Control, 16(S1), 2013, pp.203-215.

19. Ellis, B. R., Fitts, J. P., Bromhal, G. S., Mclntyre, D. L., Tappero, R., Peter, C. A., "Dissolution-driven permeability reduction of a fractured carbonate caprock". Environmental Engineering Science, 30(4), 2013, pp.187-193.

20. Garing, C., Gouze, P., Kassab, M., Riva, M., Guadagnini, A., "Anti-correlated porosity-permeability changes during the dissolution of carbonate rocks: Experimental evidences and modeling". Transport in Porous Media, 107(2), 2015, pp.595-621.

21. Smith, M., Sholokhova, Y., Hao, Y., Carroll, S., " $\mathrm{CO}_{2}$-induced dissolution of low permeability carbonates. Part I: Characterization and experiments". Advances in Water Resources, 62(12), 2013, pp. 370-387.

22. Hao, Y., Smith, M., Sholokhova, Y., Carroll, S., " $\mathrm{CO}_{2}$-induced dissolution of low permeability carbonates. Part II : Numerical modeling of experiment". Advances in Water Resources, 62(12), 2013, pp.388-408.

23. Menke, H. P., Bijeljic, B., Andrew, M. G., Blunt M J., "Dynamic three-dimensional pore-scale imaging of reaction in a carbonate at resercior conditions". Environmental Science \& Technology, 49(7), 2015, pp.4407-4414.

24. Ghommem, M., Zhao, W. S., Dyer, S., Qiu, X. D., Brady, D., "Carbonate acidizing: Modeling, analysis, and characterization of wormhole formation and propagation". Journal of Petroleum Science and Engineering, 131, 2015, pp.18-33.

25. Fan, W., Luo, K. P., Fan, M., Han, Y., "Most important mechanism of carbonate reservoir: differential corrosion". Science Technology and Engineering, 17(01), 2017, pp.15-20+48.

26. She, M., Shou, J. F., Shen, A. J., Pan, L. Y., Hu, A. P., Hu, Y. Y., "Experimental simulation of dissolution law and porosity evolution of carbonate rock". Petroleum Exploration and Development, 43(04), 2016, pp.564-572.

27. Peng, J., Wang, X. L., Han, H. D., Yin, S., Xia, Q. S., Li, B., "Simulation for the dissolution mechanism of Cambrian carbonate rocks in Tarim Basin, NW China". Petroleum Exploration and Development, 45(03), 2018, pp.415-425.

28. Shou, J. F., She, M., Shen, A. J., "Experimental Simulation of dissolution Effect of Carbonate Rock under Deep Burial Condition". Bulletin of Mineralogy, Petrology and Geochemistry, 35(05), 2016, pp. $860-867+806$
29. Pokrovsky, O. S., Golubev, S. V., Schott, J., Castillo, A., "Calcite, dolomite and magnesite dissolution kinetics in aqueous solutions at acid to circumneutral $\mathrm{pH}, 25$ to $150^{\circ} \mathrm{C}$ and 1 to $55 \mathrm{~atm} \mathrm{pCO}_{2}$ : New constraints on $\mathrm{CO}_{2}$ sequestration in sedimentary basins". Chemical Geology, 265(1/2), 2009, pp.20-32.

30. Pokrovsky, O. S., Golubev, S. V., Schott, J., “Dissolution kinetics of calcite, dolomite and magnesite at $25^{\circ} \mathrm{C}$ and 0 to 50 atm $\mathrm{pCO}_{2}$ ”. Chemical Geology, 217(3/4), 2005, pp.239-255.

31. Alkattan, M., Oelkers, E. H., Dandurand, J. L., Schoot, J., “An experimental study of calcite and limestone rates as a function of $\mathrm{pH}$ from -1 to 3 and temperature from 25 to 80 degrees C". Chemical Geology, 151(1-4), 1998, pp.199-214.

32. Zhu, W. H., Qu, X. Y., Qiu, L. W., Chen, Y., Gong, F. X., Wu, S. X., "Characteristics and erosion mechanism of carbonate in acetic acid and hydrochloride solutions, an example from the Nanpu depression”. Bulletin of Mineralogy, Petrology and Geochemistry, 34(03), 2015, pp.619-625.

33. Tan, F., Zhang, Y. F., Wang, Z. Y., Dong, Z. X., Huang, Z. L., Wang, Q. P., Gao, J. W., "Simulation experiment for the burial dissolution of different petrofabric carbonate rocks of Ordovician in the Ordos Basin". Acta Sedimentologica Sinica, 35(02), 2017, pp.413-424.

34. Davis, K. J., Dove, P. M., De Yoreo, J. J., "The Role of $\mathrm{Mg}^{2+}$ as an impurity in calcite growth". Science, 290(5494), 2000, pp.11341137.

35. Picknett, R. G., Stenner, R. O., "Enhanced calcite solubility in dilute magnesium carbonate solutions". Transactions of the British Cave Research Association, 5(1), 1978, pp.47-54.

36. Nie, J. H., Han, B. P., Gao, L., "Study on micro-mechanism karst of carbonate minerals". Analysis and Testing Technology and Instruments, 1(02), 1995, pp.33-37.

37. Han, B. P., "Study on micro-corrosion mechanism of karst". Carsologica Sinica, 12(02), 1993, pp.4-9+91-93.

38. Fan, M., He, Z. L., Li, Z. M., Yu, L. J., Zhang, W. T., Liu, W. X., Jiang, X. Q., "Dissolution window of carbonate rocks and its geological significance”. Oil \& Gas Geology, 32(04), 2011, pp.499505 .

39. Ding, Q., He, Z. L., Wo, Y. J., Zhang, J. T., Fan, M., Yue, X. J., "Factors controlling carbonate rock dissolution under high temperature and pressure". Oil \& Gas Geology, 38(04), 2017, pp.784-791.

40. Wang, M. G., Song, T. S., Xu, J. H., Li, Z. F., Tian, Z., Liu, S. C., "Characteristics and geological significance of calcite dissolution under acetic acid conditions". Science \& Technology Review, 34(18), 2016, pp. 230-235. 